\title{
Whether Developing Country Can Achieve Remarkable Progress in the Global Market by High-Tech-Huawei Company as an Example
}

\author{
Zhenchuan Jiang ${ }^{1,2}$, Xun Gong1,3* \\ ${ }^{1}$ School of Economics and Management, Beijing Jiaotong University, Beijing, China \\ ${ }^{2}$ Graduate School of Lyceum of the Philippines University, Manila, Philippines \\ ${ }^{3}$ Beijing Center for Industrial Security and Development Research, Beijing, China \\ Email: jiangzc0810@163.com, *gongxun83@aliyun.com
}

How to cite this paper: Jiang, Z.C. and Gong, X. (2019) Whether Developing Country Can Achieve Remarkable Progress in the Global Market by High-Tech-Huawei Company as an Example. Technology and Investment, 10, 47-58.

https://doi.org/10.4236/ti.2019.103003

Received: July 8, 2019

Accepted: August 28, 2019

Published: August 31, 2019

Copyright $\odot 2019$ by author(s) and Scientific Research Publishing Inc. This work is licensed under the Creative Commons Attribution International License (CC BY 4.0).

http://creativecommons.org/licenses/by/4.0/

\begin{abstract}
With the development of international trade and the formation global value chain, global economy increases rapidly and many countries can gain benefits from it. However, the gap between the rich and the poor is becoming increasingly sharp. Developed countries dominate the global trade and achieve the majority of value chain. As a big developing country, China has developed to the second biggest economy, and the biggest export volume country, but still stays at the weak stage of the global value chain. Because in China, low-value-end manufacturing is the dominating economic sector. In order to achieve more value in global trade, China desires to update the business model from traditional industries to emerging industries by developing high-tech industries. It is widely believed that an increasing amount of Chinese companies concentrate on $\mathrm{R} \& \mathrm{D}$ and innovation to gain advantage in the new wave of global economy. Huawei, a remarkable Chinese high-tech company which develops from a sale agent firm to one of the most innovative companies in the whole world, will be presented in this paper to show the importance of high-tech and updating industrial structure for a company and countries.
\end{abstract}

\section{Keywords}

Developing Countries, High-Tech, Market, Huawei

\section{Introduction}

It is widely known that international trade plays an extremely important role in

${ }^{\star}$ Correspondence author. 
the development of global economies. Both developed countries and developing countries are necessary and significant for the progress of globalization. From Adam Smith, David Ricardo to Heckscher and Ohlin, a couple of trade theories state the importance of co-operation and division between different countries [1]. It is believed that one country should concentrate all domestic resource to produce the most effective production to export for benefits, and import the goods which this country has less capacity. With the development of globalization, the world's economies are becoming increasingly powerful, but the wealth inequality between developing countries and developed countries is more serious. Due to the international division, developing countries have to keep underprivileged position in global trade. In 1980s, the income of the richest 15 countries is 44 times bigger than the income of the poorest countries, but this data becomes to 52 times in 1990s and 62.3 times in 2000s. In 2010s, this data is 55.8 times [2]. In addition, in 2008, United Nations University estimates global Gini coefficient at $89 \%$, which is $66 \%$ in 1980 [3]. According to New Trade Theory, developed countries, always with advanced experience and high-tech can gain the first mover advantages and dominate the international market soon [1].

With the related literature, this paper takes China as an example and focuses on the problem in the developing process and analyzes how developing countries can gain more effective and rapid progress. As a typical firm, Huawei will be analyzed in this paper. In the last decade, global GDP growth stays a slowly level from $-1.687 \%$ by 2009 to $3.035 \%$ by 2018 , because of the financial crisis of 2008 [4]. However, China's economy developing keeps higher growth at average $7.95 \%$ from 2009 to 2018, which is twice bigger than the global data. One of the reasons is that China pays more attention to high-tech production. As a milestone of China's high-tech company, Huawei has been keeping an outstanding level for last 10 years. Huawei’s operation revenue arrives almost $¥ 125.2$ billion in 2008 and increases to $¥ 721.2$ billion in 2018 [5] [6]. According to Huawei’s financial report from 2008 to 2018, in every financial year, Huawei can keep approximately $20 \%$. The flourishing development of China and Huawei is wealth to be analyzed to other developing countries how to achieve an advantage position in global trade. This paper may be positive to other companies and countries to consider a new business model in sharp competition, though single case may be limited.

In the following sectors, the author will introduce the background of the study, statement of the problem, objective, hypothesis, methodology, significance and limitation of the study.

\section{Statement of Problem, Objective and Hypothesis}

However, increasing scholar and expert realize that, with the development of international business, the wealth inequity between the poor and the rich has been increasing seriously. In term of World Bank, between 1995 and 2014, the global wealth grew from $\$ 690$ trillion to $\$ 1143$ trillion, but wealth per capital from 
high-income countries is 52 times bigger than the figure in low-income countries [7]. In addition, the richest people in the planet occupy above $\$ 2.7$ trillion which is more than $\$ 2.2$ trillion, the number from 3.5 billion bottom wealth population. In addition, the $1 \%$ top rich people have almost $25 \%$ wealth share of the whole world in 1980s, the share percentage increases to $40 \%$ by 2016 [8]. Therefore, the economies from developing countries are supposed to be paid increasing attention to.

As a result of reading international theories and global trade facts, the author desire to figure out how developing countries can achieve more benefits from international trade and narrow the gap between emerging countries and advanced countries. Whether high-tech company from developing country can attain success.

The hypothesis of this research is that whether developing countries can achieve more benefits by high-tech. In order to develop increasingly rapidly and efficiently, developing countries ought to upgrade industrial structure and blossom new products such as high-tech industry. Some high-add-value industries need to be established in developing countries. This is due to the fact that in traditional global business, developing countries have advantages in manufacturing exporting because of lower costs, and natural resource exporting such as oil and natural gas, but developed countries have technological advantages. Therefore, it may be a good option for developing countries to transfer domestic resource to produce high-add-value product to obtain more benefits. As a big developing country, China gain a great number of benefits from international business, but the development of China, some problems have to be concluded, so industrial structure in China ought to be upgraded to achieve higher target. This paper concludes how China develops from a poor agricultural society to the second strongest economy power in the world and means to provide some ideas which may be beneficial for developing countries to achieve more benefits from international trade.

\section{Literature Review}

\subsection{Situation of International Business}

As known to all, international business plays an important role in the development of the whole world, hundreds of years ago, trade generates across different countries due to different social and natural resource. Smith issues absolute advantaged theory in 1776 and encourage a nation to produce more effective items and free trade to others. His theory has been upgraded by Ricardo Heckscher Ohlin and other specialists. Due to New Trade Theory, first mover advantages and economics of scale which can suggest how companies can gain competitive advantages and decrease costs. Product life-cycle theory is issued by Vernon and suggests that in order to reduce costs, production location changes from developed counties to developing countries. This theory explains the fact that multinational corporation invest to developing countries, especially, in manufactur- 
ing, due to lower cost, particularly cheap labor force [1]. With the development of globalization, international division and global value chains are generated [9]. Advanced companies from developed countries can select good location to produce more efficiently. Recently, it is universally known that compared with traditional industry, technology-oriented industry has been play increasing important role, high-tech multinational corporation such as Apple Inc. and Samsung which are becoming the most famous in the world. And they establish produce basement in China due to cheap and hard-working labor force [10]. Therefore, high-tech exporting has paid more attention to. According to Global Economy, China has overtaken the US to be the leader in global high-tech exporting since 2004. Chart 1 below shows in 2010, exporting from China account for $\$ 406.9$ billion which is bigger the sum from Germany and the US which rank No. 2 and No. 3 [11].

However, the huge amount of high-tech exporting does not mean the huge income. Since 10 years ago, some researches discuss the profit from high-tech exporting. It can be analyzed that the value chain in ipod which is the product from the Apple Inc. and notebook from Hewlett-Packard, and all ipod and notebook are manufactured in mainland China by a Taiwanese company. The result shows that only $2 \%$ margin can be achieved by manufacturing service in the value chain of high-tech exporting [12]. From the statistics, China has a huge number of ipod exports, but China takes a little percentage of the profit. In addition, the member from Asia Development Bank Institute, Xing shows that the exporting of iphones and computers just account for $3 \%$ profit of the total value due to the fact that China does not have technology advantages. Nevertheless, and believes that $82 \%$ of China's high-tech exports are produced by Foreign Direct Investment (FDI) [13]. According to the research, it can be concluded that, the income from China's high-tech exports is not as big as statistics. The high-tech exporting of China is similar to labor-intensive manufacture and exports, for instance Apple Inc products and personal notebook should be excluded from the high-tech classification, and the statistics mistakenly estimate the exporting's real attribute to the development of China's economy [14]. Since 2001 , more than $50 \%$ of the high-tech exporting are produced by companies generated by foreign direct investment and this percentage increases to $85 \%$ by

\footnotetext{
1. China

2. Germany

3. USA

- 4. Singapore

5. Japan

6. South Korea

7. France

8. UK

9. Netherlands

10. Malaysia
}

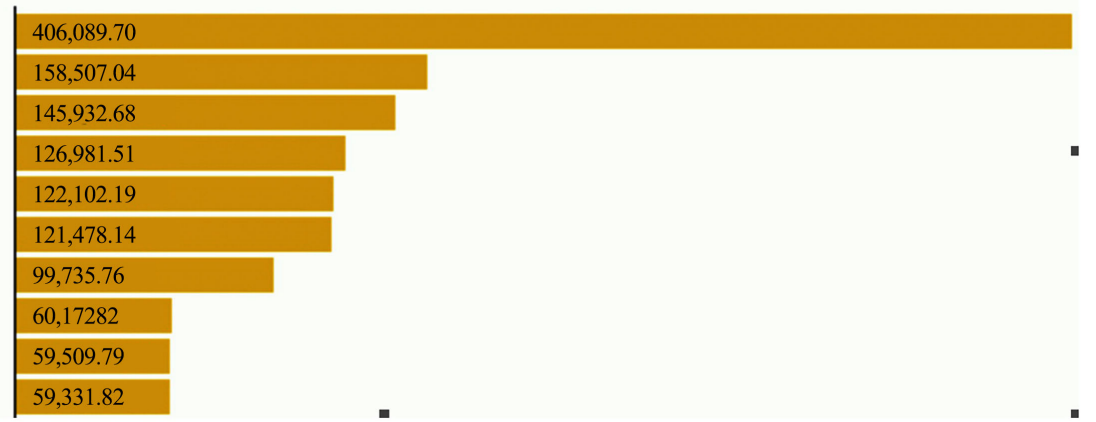

Chart 1. High-tech exports, 2010. Million US dollars, Source: TheGlobalEconomy.com. 
2003, which means transnational companies from developed countries regard China as a export platform [15]. Therefore, Chinese domestic companies do not have such a high level in technology industry, remarkable statistics of high-tech exporting cannot represent the real quality of China's high-tech industry.

\subsection{China Achieves Remarkable Because of Comparative Advantages}

Since 2001, China has been a member of WTO, because of the rapid development of industrialization and exports benefits, China achieves a remarkable progress in economics and becomes the secondly strong economy power. In term of the characteristic of China, the theory of comparative advantages can be proved. China has a great number of comparative advantages in resource-intensive and labor-intensive industry which contribute a lot to the development of China's economy. However, increasing Chinese researcher and entrepreneur realize the unbalance of economies structure which ought to be improved. It can be concluded that in order to develop economics rapidly and effectively, the only method is to update and transform its industrial structure. This is due to the fact that China's economy is based on exporting of resource-intensive and labor-intensive productions. A research shows that there is no evidence to prove Chinese exporting has significant technical upgrade, though the quality of product has improved [16]. In addition, it is stated that "the quality improvement of capital-intensive product and the enhancement of trade competitiveness of China are not due to the traditional R\&D or the local enterprises imitation and improvement of foreign cash management experience and technology, but large introduction of foreign capital and the spillover effect on local enterprises of foreign-funded enterprises, namely processing trade lead by foreign capita l" [17]. It is concluded that such comparative advantages in China lead the result as exporting of primary products, slow technological upgrade, low demand elasticity, and diminishing returns of scale, which means that disadvantageous position is difficult to change for developing countries if they insist comparative advantages [18]. Therefore, industrial upgrade ought to be paid great attention. It can be believed that with the development of economics, resource and attention ought to be transferred from primary manufacturing industry to service and consumer-oriented industry, from low-add-value industry to high-add-value industry because of the fact that profit ratios between various industries generate different interests.

\subsection{A New Business Model Is Expected to Be Considered}

With the development of digitization and technology, the traditional manufacture will move to Industry 4.0, which means that it is possible to connect information, objects and people. This phenomenon will stimulate innovation extremely stronger in next few years and trigger the wave of technology. Thus, the importance of innovation and Research and Development $(\mathrm{R} \& \mathrm{D})$ ought to be paid attention to 
[19]. It is widely known that high-tech industry will be the fast-expanding sector and play an extreme significant role in the development of whole world's economy. In-depth research, it is necessary to invest in research and innovation to develop high-tech industry. High-tech exporting can be defined by scientific instruments, aerospace, computer, pharmaceutical, smart-phone and electrical machinery industries [20]. Similarly, in order to blossom the high-tech, knowledge-based industry need to be established, which means it is necessary and crucial to invest substantively in innovation, $R \& D$, human capital and skills [21]. According to First-mover advantages, a company with new products may pro-dominate the market easily. In addition, the first firm is in a strong position to decrease the costs and fit the penetration pricing approach without obvious barrier [22].

\section{Methodology and Case Study}

It can be concluded by other research that China has limited benefits from the huge amount of high-tech exports. However, this paper focuses on a new trend, China's high-tech industry has improved rapidly.

In this paper, the method, case study will be used to verify author's hypothesis. China, especially Huawei will be analyzed by SWOT. This dissertation mainly adopted deductive research. The quantitative analysis refers to measure magnitude and study a case of Huawei to make a result.

\subsection{Highlights of High-Tech in China}

In former part of this paper, it can be known that China has good statistics in high-tech exports but a few benefits. However, some data shows the situation may be different now.

An increasing number of Chinese companies pay attention to high-tech industry, Research and Development expenditure has been increasing for years which can be shown in Chart 2. As mentioned in former sector, the GDP of China increases rapidly, so, it can be concluded that the investment in R\&D has been climbing since 2010 .

The following Chart 3 can show that from 2010 to 2017, Foreign Direct Investment (FDI) in China decreases from $\$ 243.70$ billion to $\$ 168.22$ billion. Except 2011 and 2013, the amount decreases each year. However, at the same period, high-tech exports increase from $\$ 406.90$ billion to $\$ 504.38$ billion, though there are some fluctuations during the years. The opposite relationship between FDI and high-tech may reveal that the increases of high-tech exports in China are generated by domestic investment instead of FDI.

It can be concluded that Chinese domestic power is play an increasing important role in high-tech industry. More and more resources are spent in R\&D and innovation. It is widely believed that China's experience has positive effects to other developing counties. As a milestone of China high-tech industry, Huawei is wealthy to be presented. 


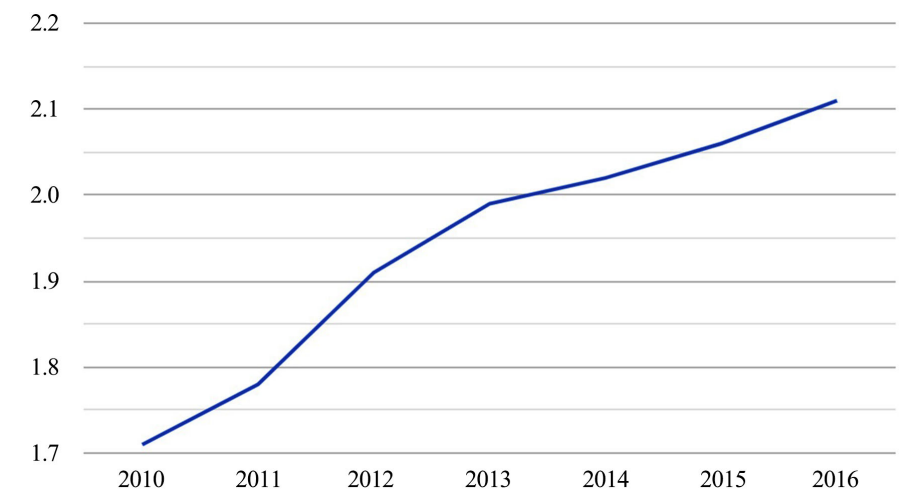

Chart 2. Research and development expenditure in China from 2010 to 2016. The percent of GDP, Source: TheGlobalEconomy.com.

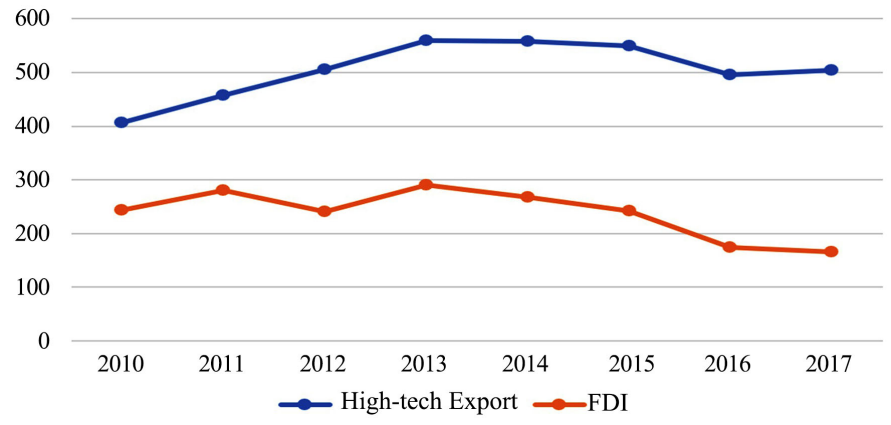

Chart 3. High-tech exports and FDI in China from 2010 to 2017. Billion US dollars, Source: TheGlobalEconomy.com.

\subsection{Introduction and Developing Progress of Huawei}

Huawei Investment \& Holding Co., Ltd. is one of the most famous Chinese transnational enterprises in the world, which is founded in 1987 by Ren Zhengfei, a retired soldier. At the beginning, Huawei is a sale agent for Private Branch Exchange (PBX) for a Hongkong producer. In 1990, Huawei initiates to research and commercialize PBX to targeting hotel and small companies. Before the new century coming, Huawei pays attention to global market and established R\&D centers oversea. At the end of 2007, Huawei has been a partner of all the topping operators in the Europe. One year later, Huawei has been recognized as one of topping 10 the most influential companies in the world by the Business Week. Meanwhile, Huawei ranks No. 1 by ABI in mobile broadband device which has shipped more than 20 million units and ranks No. 3 in the sale volume of mobile network equipment by worldwide market share. In the next 10 years, Huawei develops with stable and rapid pace and becomes the world's largest producer of telecommunications equipment and systems, and the leading cell phone produce in the planet. At the end of 2018, Huawei achieves revenue over 100 billion US dollars in a financial year, and sells exceeded 200 million cellphones, who is the top three cell phone producer. It is proud to the fact that $48 \%$ of Fortune Global 100 companies and 211 of the Fortune Global 500 companies select Huawei as the partner for digital transformation. At the end of 2018, Huawei has estab- 
lished 36 joint innovation centre and $14 \mathrm{R} \& \mathrm{D}$ institutes in the whole world.

Huawei is a $100 \%$ private enterprise held by employees whose Employee Shareholding Scheme can be implemented by the Union of Huawei. It means that Huawei is wholly owned 96,768 employee shareholders, without government agency or outside organization shares.

Recently, as one of the most famous high-tech firm in the world, Huawei has a range of products and services including consumer business, carrier business and enterprise business. Huawei's business is comprised by dozens of products and service, such as cell phones, lab-tops, tablets and network service, intelligent service and other dozens. According to the following chart, Huawei's revenue in 2018 has climbed to 721,202 million Renminbi, which is $19.5 \%$ increase than 2017's, especially in enterprise business and consumer business.

\subsection{Strength of Huawei's Developing}

From 1987 to 2018, it takes Huawei 31 years to become such a huge giant, from a sale agent, which is a milestone for China's firm evolution. It can be concluded that innovation, which affect not only in technology but also in corporation governance plays an extreme important role in Huawei's development.

\subsubsection{Innovation and R\&D}

Huawei pays great attention to innovation and R\&D. Since 1990, Huawei has embarked on independent research, and regarded overseas R\&D as a key point. At the end of 2018, Huawei has 36 joint innovation centers and $14 \mathrm{R} \& \mathrm{D}$ institutes, and more than 80,000 employees who account for $45 \%$ of the total workforce, are involved in innovation and R\&D. Meanwhile, Huawei spends more than $10 \%$ of sale revenue into R\&D every year, in 2018 the cost of R\&D increases to 101,509 million RMB, which occupies $14 \%$ sale revenue of 2018. In the last 10 years, it takes Huawei more than 480 billion RMB in R\&D investment. Such expenditure generates 87,805 patents including 43,371 patents granted in China and 44,434 patents granted overseas [6]. Now, Huawei has remarkable technology advance in global competition, such as wireless network, software, cloud core networks, smartphone domain, personal computer domain and AI domain. Huawei's advanced technology and high quality are the reasons for the preference from consumers from the whole world.

\subsubsection{Innovation in Organizational Structure}

Huawei insists unique corporate organizational structure. Ren zhengfei is the founder of Huawei rather than a monopolist in the company. The BOD selected by 96,768 employee shareholders, is the most powerful organization in this company which is responsibility to corporate strategy. It undertakes the mission of leading the company forward, exercising corporate strategy and operational management decision-making power, and ensuring that the interests of customers and shareholders are maintained. The highest leader in Huawei is the rotating chairman of the BOD, who has 6-month term of office and generated by 17 
selected directors. The corporate organizational structure of Huawei may be positive to run the company more effective, make employees increasing enthusiastic. Meanwhile, it helps to avoid the risk of concentration of power, due to the organizational democracy.

\subsubsection{Innovative Organizational Culture}

On the one hand, Huawei insists customer-centric corporate core value, which means that innovation and R\&D of Huawei based on requirements of consumer, lead technology advance. Huawei create value for customers and respect their requirements, which means that Huawei provides innovative, secure, stable and trustworthy services and products to partners and clients. On the other hand, Huawei depends on their dedicated workforce, which means that stimulating dedication is another core value. A great number of Huawei's employees are involved in corporate governance to extend their responsibility and enthusiasm. In addition, Huawei is a responsible enterprise, who advocates environment-friendly development, producing more effective products which can improve energy efficiency by $15 \%-26 \%$. Huawei guarantees smooth communications for more than $30 \%$ of the population in the whole world and provide technical services $24 / 7$ in 365 days every year. Moreover, Huawei provide study offer for over 4700 students from 108 countries and regions due to the Seed for Future Program in order to cultivate increasing people involve in digital and technical society.

\subsubsection{Effective Developing Strategy}

At the beginning of business, Huawei focus on small companies and rural market in China. This method is beneficial to attain a great number of consumers in Chinese rural, meanwhile, Huawei avoids serious competition. After capital and reputation accumulation, Huawei expands its business map into metropolitan area by initiating wireless GSM-based solutions by 1998. The strategy of globalization generates 100 million US dollars sale for Huawei in 2000. Producing sales over 500 million US dollars from overseas market for Huawei just takes 2 years by 2002. Increasing global business has been expanded extremely rapid, overseas contract orders exceed domestic contract orders for the first time by 2005 . Therefore, taking an appropriate strategy in different stages of development may be positive to the company.

\subsection{Opportunities for Huawei's Developing}

Huawei seizes the opportunity of the development of communication and network, and becomes a telecommunication giant producer. This last decade, the blossom of smartphone is growing dramatic fast, smartphone is one of the most important tools for people. Huawei grasps this great chance and develop rapidly, since 2015, Huawei has become one of the top 3 smartphone player, and in 2018 Huawei ships 200 million smartphones in the whole world. Huawei already attain spectacular benefits from globalization, so, with the increasingly rapid development of digital communication and information technology, Huawei has a bigger business map and market, and ought to insist globalization, as an industry 
giant may lead the trend and establish standard of the industry. Depended on Huawei's mass base, new products can be easily accepted by existing customers of Huawei. Great reputation, innovative products and quality services of Huawei may attract an increasing number of partners and consumers from the whole world. It is widely known that the $5 \mathrm{G}$ aging is approaching, facing the great opportunity, Huawei is ready to launch. Thanks to the strategy of Huawei's managers, the company has begun $5 \mathrm{G}$ innovation and R\&D since 2009 and applied 2750 crucial patents for 5G. In addition, Huawei is the first company to figure out how to commercialize 5G. Due to advanced technology, Huawei has capability to use the simplest $5 \mathrm{G}$ data base station but the best performance, with more effective maintenance. Hence, the technical revolution for $5 \mathrm{G}$ is a great opportunity for Huawei to expand its business.

\subsection{Weakness and Threats of Huawei's Development}

However, from financial perspective, a disadvantage of Huawei cannot be ignored, as an unlisted company, it is unfavorable for public financing by issuing stocks. In addition, the democracy of Huawei's corporate governance may decrease efficiency for company running, and 6-month rotating chairman of the BOD may be negative for stable and sustainable corporate strategy.

However, Huawei has some threats from globalization and international trade. Due to comparative advantages, division and cooperation, one company's product may be the raw material for another firm, Huawei need suppliers from the whole world. Therefore, cost of Huawei's product may be influenced by suppliers such as price fluctuation, corporate strategy and domestic policy. In addition, it is widely known that free trade can be easily affected by government policy due to trade deficit and political requirement. Recently, the news between United States and Huawei grasp the whole word's attention. Without obvious evidence, Donald Trump put Huawei on the blacklist on May 15th, and forbid American companies sale any products to Huawei, American department, enterprise even academic institute terminate the cooperation with Huawei, one after another. Since 2018, the US telecom giant AT\&T break the agreement unilateral, one day before the conference under government's pressure. In addition, the US authority bans any equipments and products for Huawei's 5G to entry American market. Therefore, the unreasonable suppress from government is a big threat to Huawei.

\section{Conclusions}

From the development of China and the case of Huawei, it can be concluded that international trade is dramatically important to economy, and attaining competitive advantages can take a positive position in international trade. For a company or a country, formulating a stable, sustainable and efficient strategy is extremely crucial, which is the guideline for developing. In order to surpass traditional trade model, developing countries ought to develop some high-value-added industries rather than a role in low-value-added chain. High-tech companies from devel- 
oping countries may learn from giant or pioneer companies, and use own advantages to reduce cost or satisfy costumers' deeper requirements.

In the new era of technology and innovation, it is significant to innovate some fresh and irreplaceable technique to attain first mover advantages which have possibilities to achieve advanced position and dominate the market. The related statistics reveals that China's high-tech industries are booming developing, Huawei is an outstanding sample. In addition, Huawei shows the extreme importance of $\mathrm{R} \& \mathrm{D}$ and innovation. In the 30-year developing of the company, high-tech helps Huawei booming. The core technology is the most important competitiveness in the global trade. With the advent of the $5 \mathrm{G}$ era, Huawei is ready to take the opportunity to create more value for its own and the society.

In summary, technology creates values for companies and the companies are willing to spend more resource on innovation and $R \& D$. It is the new model for business and society.

\section{Limitation}

This paper utilizes Huawei as the case to analysis how high-tech company in developing countries can attain positive position in global trade. However, Huawei and China are limited simple may not be representative or they have unique advantages that other countries may be different to learn from.

\section{Conflicts of Interest}

The authors declare no conflicts of interest regarding the publication of this paper.

\section{References}

[1] Charles, W.L. (2000) Hill. International Business 2000. McGraw-Hill, New York, 55-300.

[2] UNCTD (2014) Eliminating Inequality through Trade and Development in the Development Agenda, after 2015. United Nations Conference on Trade and Development, Geneva, 2. (In Chinese)

[3] Kate, P., Richard, W. and Roberto, V. (2000) World Economy Forum. https://cn.weforum.org/agenda/2015/10/273/

[4] World Bank (2018) https://data.worldbank.org/indicator/ny.gdp.mktp.kd.zg

[5] Huawei (2008) Huawei Annual Report.

[6] Huawei (2018) Huawei Annual Report.

[7] Word Bank (2018) World Bank Report Finds Rise in Global Wealth, but Inequality Persists.

https://www.worldbank.org/en/news/press-release/2018/01/30/world-bank-report-f inds-rise-in-global-wealth-but-inequality-persists

[8] Gabriel, Z. (2019) Global Wealth Inequality National Bureau of Economic Research. http://www.nber.org/papers/w25462

[9] Linden, G., Kraemer, K.L. and Dedrick, J. (2007) Who Captures Value in a Global Innovation System: The Case of Apple's iPod. Personal Computing Industry Center, Irvine, CA. 
http://citeseerx.ist.psu.edu/viewdoc/download?doi=10.1.1.419.2289\&rep=rep1\&type $=\mathrm{pdf}$

[10] Pisano, G.P. and Teece, D.J. (2017) How to Capture Value from Innovation: Shaping Intellectual Property and Industry Architecture. California Management Review, 50, 278-296. https://doi.org/10.2307/41166428

[11] Global Economy (2019) Business and Economic Data for 200 Countries. https://www.theglobaleconomy.com/rankings/High_tech_exports/

[12] Jason, D., Kraemer, K.L. and Greg, L. (2008) Who Profits from Innovation in Global Value Chains? A Study of the iPod and notebook PCs. Sloan Industry Studies Annual Conference, Boston, MA, 2-10.

[13] Xing, Y. (2012) The People's Republic of China's High-Tech Exports: Myth and Reality. ADBI Working Paper 357. Asian Development Bank Institute, Tokyo.

http://www.adbi.org/working-paper/2012/04/25/5055.prc.high.tech.exports.myth.re ality/

[14] An, T., Fan, Y. and Zhang H. (2011) An Analysis of the Model of China's Industrial Restructuring and Upgrading-Borrowing Ideas from the Experience of Japan, Energy Procedia, 5, 1461-1466. https://doi.org/10.1016/j.egypro.2011.03.250

[15] Naughton, B. (2007) The Chinese Economy: Transitions and Growth. MIT Press, Cambridge, MA.

[16] Amiti, M. and Freund, C. (2008) The Anatomy of China's Export Growth, Policy Research Working Paper 4628. The World Bank Development Research Group, Trade Team. https://doi.org/10.1596/1813-9450-4628

[17] Zhang, X. and Sun, J. (2007) An Analysis of China's Global Industrial Competitive Strength Based on Vertical Specialization. Frontiers of Economics in China, 2, 51-73. https://doi.org/10.1007/s11459-007-0003-3

[18] Xiong, J. and Qureshi, S. (2013) The Quality Measurement of China High-Technology Exports. Procedia Computer Science, 17, 290-297. https://doi.org/10.1016/j.procs.2013.05.038

[19] Shin, N. and Kenneth L.K.K. and Dedrick, J. (2009) R \& D, Value Chain Location and Firm Performance in the Global Electronics Industry. Industry and Innovation, 16, 315-330. https://doi.org/10.1080/13662710902923867

[20] Śledziewska, K. and Akhvlediani, K. (2017). What Determines Export Performances in High-Tech Industries. Central European Economic Journal, 48, 37-50. https://doi.org/10.1515/ceej-2017-0006

[21] Viorica, B., Albulescu, C.T., Farkas, Z.-B. and Drăghici, A. (2015) Determinants of the High-Tech Sector Innovation Performance in the European. Procedia Technology, 19, 371-378. https://doi.org/10.1016/j.protcy.2015.02.053

[22] Markides, C. and Sosa, L. (2013) Pioneering and First Mover Advantages: The Importance of Business Models. Long Range Planning, 46, 325-334.

https://doi.org/10.1016/j.lrp.2013.06.002 